\section{P-449 腎細胞癌における予後因子の検討Nuclear grade, Ki-67および核DNA憲について}

\begin{abstract}
昭和大学藤が丘病院 泌尿器科1)
小野寺恭忠 ${ }^{1)}$ 後藤 隆太 ${ }^{1}$ 藤井伸勝1) 太田道也 $\left.{ }^{1}\right)$

池内隆夫”松本恵一1) 甲斐祥生 ${ }^{\prime}$

日的腎細胞癌の予後は, 一般に不確定な事が多い。そこで nuclear grade, Ki-67 expression および核DNA量が予後因子となり得るか検 尉した。対象と方法腎摘出術を受けた腎細胞癌患者116例におい て Kaplan-Meier plots と Cox multiple hazard regression analysis. 孝用いて それぞれの予後因子について検討した。結果 Nuclear grade( $\mathrm{P}=0.0001)$ やリンパ節転移 $(\mathrm{P}=0.0001)$, 腎静脈浸潤 $(\mathrm{P}=0.0001)$ 腎 周囲脂肪組織への浸潤 $(\mathrm{P}=0.002)$ および遠隔転移 $(\mathrm{P}=0.0001)$ の有無は それぞれ予後に統計学的有意差を認めたが, 多变量解析では nuclear grade と遠隔転移の有無のみが独立した予後因子であった。 しかし, low(G1,G2) or high(G3) grade tumors.の間では有意差を認め たが, low grade tumorでは Gradel とGrade2の間には有意差は見られ なかった。Ki-67を用いた㭘討ではlow grade tumorの間で7\%末満 が $7 \%$ 以上に比して $(\mathrm{P}=0.0001)$ 有意に予後良好であった。DNA ploidyは、 high gradeではnondiploidが多くS-phaseが高率で, low grade ではほとんどがdiploidを示しS-phaseが低率であった。しかしlow grade tumorでは，核 DNA量は有意差を認めず予後因子となり得な かった。結語Nuclear grade およびKi-67 indexは腎細胞癌患者の予後 を決定するのに有用であった。
\end{abstract}

督細胞癌 Nuclear grade Ki-67

\section{P-451堅細胞癌における腫瘦内漫潤CD8+リンパ 球の增殖（活性）と長期予後との関係}

東北大学 医学部 泌尿器科1) 東北大学大学院 病理形態学分野 2 石巻日赤病院 泌尿器科 ${ }^{3}$ 仙台社会保険病院 泌尿器科 4 !

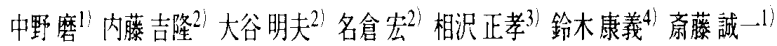

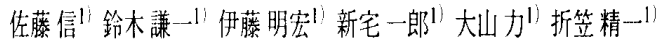

すでに、我々は大腸癌に扮ける腫瘍内浸潤 $\mathrm{CD} 8+$ リンパ球は。 Dukes分類と独立した術後生存率を良くする因子であることを報 告し、腫瘍免疫の存在を示した。今回、この概念を応用し、腎摘 出術を施行した222例のヒト腎細胞癌に掞けるこれらリンパ球の 臨床病理的意義と長期予後との関係について検討した。ヒ卜腎細 胞癌においては、組織学的異型度、病理学的病期分類が進むにつ れ、また、癌細胞のKi-67陽性摔が高いほど、腫瘍内浸潤CD8+リ ンパ球の浸潤が高度となり、それ内え、単变量解析で生存率を悪 くしていた。腫瘍内浸潤CD8+リンパ球が高度な群78例を抽出して 検討すると、これらリンパ球の標識率の高い群（增殖活性の高い 群)では生存率が良いことが単変量・多変量解析で示された。 卜腎細胞癌において、癌の曹性度が進むにつれ癌細胞内への浸潤 $\mathrm{CD}{ }^{+} \mathrm{T}$ 細胞が多くなることが示された。よって、それは癌の悪性 度に比例している印象を与えた。さらにこれらリンパ球の増殖能 が高度な群に扔いては生存率が良かった。つまり、腫瘍内のCD8 ${ }^{+}$ T細胞の浸潤がある程度あり、かつ、それがある刺激を受けてい る例ではこれら浸潤りンパ球は癌に対する腫啺免疫として機能し 生存率を良くしていることが推測された。

腎細胞癌 腫瘍内浸潤リンハ球 腫瘍免疫

\section{P-450 VHL蛋白結合蛋白(VBP-1)は腎細胞癌の腫 瘍マーカーになり得るか？}

\author{
清水 公治1) 伊勢田 徳宏 ${ }^{1)}$ 横山雅好11
}

【目的】腎細胞癌の原因遺伝子であるVHL癌抑制遺伝子、この遺 伝子産物に結合する蛋白質の一つにVBP-1がある。既にモノクロ 一ナル抗体を作製して検討しているが、今回ヒト血清中でも影響 を受けない抗VBP-1抗体を作製した。【方法】雌BALB/cマウスにり コンビナントVBP-1とヒト血清をあらかじめ反応させたものを抗 原として免疫した。【結果】免疫組織染色で作製抗体反応前にヒ 卜血清を反応させると、今までの抗体では染色できなかったが、 今回作製した抗体ではヒト血清を反応させないものと同様に染色 できた。摘出腎細胞癌組織の抽出液よりウエスタンブロットで VBP-1の存在を確認できた。摘出腎細胞癌部分とコントロール腎 部分を比較した場合、腎細胞癌部分の方がVB-1発現が強かった。 【結論】今までの抗VBP-1抗体では免疫組織染色、細胞株抽出液の ウエスタンブロットには使用できたが、ヒト血清が関わると使え なかった。今回作製した抗体はその問題点を克服し、摘出組織の 抽出液よりウエスタンブロットでVBP-1の存在を確認でき、睯細 胞癌組織のVBP-1発現が強い事がわかった。

餐細胞癌 VHL VBP-1

\section{P-452 腎細胞癌症例における血清ＩＡＰ值につい $\tau$}

\section{順天堂大学医学部 泌尿器科11}

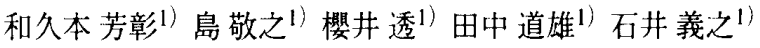
丸山修1) 藤田 和彦 1) 坂本 善郎1) 藤目 真 ${ }^{1)}$

【目的】 Immuno suppressive Acidic Protein(IAP)は、宿主のマクロファ 一ジ・多核白血球・肝細胞などで産生される分子量約50.000の糖 蛋白である。卵巣癌などで腫瘍マーカーとして用いられることが あるが、腎細胞癌においても50-80\%台の陽性率を示すと言われて いる。本研究は、腎細胞癌症例の背景因子と血清IAP值との関係 につき検討することを目的とした。【対象および方法】146例の未 治療腎細胞癌症例を対象とし、治療前血清IAP值と腫瘍径・TNM 各因子・赤沈値・CRP值との関係について検討を加えた。血清IAP

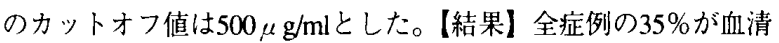
IAP高值を示した。腫場径、T-stage と血清IAP值との間に関連が何 われ、統計学的にも有意であった。総括】従来報告されていた ほど腎細胞癌で血清IAP值陽性率は高くなかった。血清IAP值は腫 瘍径と病期の進行に関連する可能性が考えられた。 